\title{
DELINEATION AND ZONATION OF FLOOD PRONE AREA IN LOWER AJOY RIVER BASIN
}

\author{
Hasibur Rahaman Molla \\ Assistant Professor, Department of Geography, \\ Sivanath Sastri College, Kolkata, India \\ Email: hasiburmollavb@gmail.com
}

\begin{abstract}
River Ajoy is notorious for its flood fury in central Bengal. It is a rain fed river and during the monsoon period it frequently inundates its floodplain causing havoc to the bank dwellers. The lower Ajoy river basin, which extends from Pandabeswar (23 $\left.44^{\prime} N, 87^{\circ} 17^{\prime} \mathrm{E}\right)$ to Katwa $\left(23^{\circ} 39^{\prime} N, 88^{\circ} 08^{\prime} \mathrm{E}\right)$, is much more susceptible to flood. On the basis of flood frequency and duration of inundation the whole lower Ajoy river basin has been demarcated by four zones i.e. severe flood prone zone, moderate flood prone zone, Low flood prone zone, and Flood free zone. The nature of damages caused by floods distinctly varies from one zone to another. The paper deals with the delineation of flood prone areas in the basin giving emphasis on the basis of demarcation of different zones, their type and characteristics. It is one of the most important soft approaches by which we can mitigate the flood hazard effectively without any structural intervention.
\end{abstract}

Key words: Inundation, Floodplain, Bank Dwellers, Flood Frequency, Hazard.

\section{Introduction}

Flood can be defined as a body of water which rises to overflow the land which is normally not submerged (Ward, 1987). Flood is a serious environmental hazard in West Bengal particularly in monsoon and post monsoon period. The Lower Ajoy river basin is a well-known flood prone area. Almost every year a large tract of the river basin gets inundated and brings about great geomorphic and socio-economic consequences. Directorate of Irrigation and Waterways Department, Govt. of West Bengal, has made attempts to control flood problems by embanking the river. But floods continue to occur defying the embankments or other engineering constructions. The flood hazard comprises many aspects including structural and erosional damage, loss of life and other materials, disruption of socio-economic activities including transport and communication system and spoiling of agricultural land and so on ( Hewitt and Burton 1971 ). Flood plain zonation and delineation of flood prone area may be an important measure to mitigate the flood hazard along with awareness of the people. The major objective of the study is to understand the flood intensity, periodicity, seasonality, and its spatio-temporal variations and to delineate the different zones on the basis of present flood character of the basin.

\section{Materials and Methods}

The major sources which have helped to identify the zones are the Survey of India top sheets

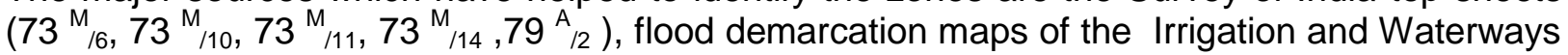
Directorate , Govt. of West Bengal. Remote Sensing data (IRS - IC \& ID, LISS - III) for mapping the extent of flood affected areas. Ground reality of the flood affected areas has been checked by the extensive field surveys conducted from time to time. Co-relation co-efficient has been calculated to show the relationship between flood affected areas and number of affected moujas areas (Figure: 3 ). The study area i.e. the Lower Ajoy river basin geographically extends from $23^{\circ} 30^{\prime} \mathrm{N}$ to $23^{\circ} 45^{\prime} \mathrm{N}$ latitudes and from $87^{\circ} 20^{\prime} \mathrm{E}$ to $88^{\circ} 15^{\prime} \mathrm{E}$ longitudes (Figure:1). It occupies an area of about 2816.65 sq. $\mathrm{km}$. The river Ajoy is a right bank tributary of the Bhagirathi River. The total length of the Ajoy River is about $299 \mathrm{~km}$ but only $145 \mathrm{~km}$ fall under the study area. The Lower Ajoy river basin covers 7 blocks in Burdwan district and 5 blocks in Birbhum district (W.B.). There are 619 moujas in under 12 C.D. blocks and out of the total 493 moujas are flood prone. Extensive field surveys have been conducted to acquire primary data. Secondary data have been collected from Directorate of Irrigation and Waterways Department, Govt. of West Bengal, Zilla Parishad Offices of Burdwan and Birbhum districts. 
Figure 01: Key Map

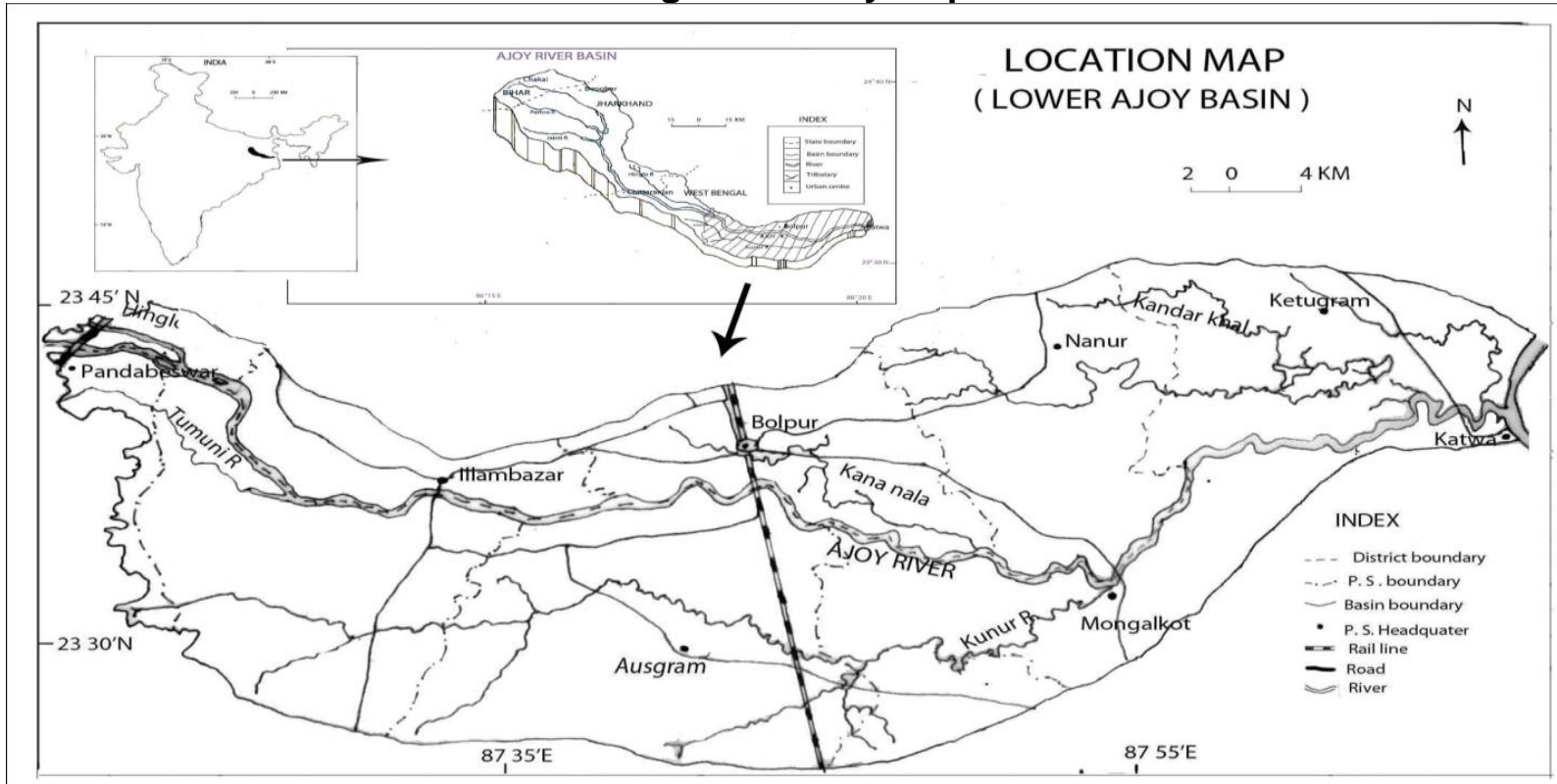

\section{Results and Discussion}

Table-1 shows that the trend of flood affected area has gradually been increased since 1956. The minimum affected area was in the flood of 1984 and about 305.72 square kilometres areas of the basin was flood affected, which accounts for 10.85 per cent of the total Lower Ajoy Basin. On the contrary, the maximum inundation has been taken place in the flood of 1978 and about 1680 square kilometres areas was flood affected, which accounts for about 59.64 per cent of the total area. The flood occurred in the year of 2000 was also notorious. About 1488 square kilometres areas comprising total 369 mouzas were affected by the flood of 2000 and it accounts about 52.82 per cent of the total Lower Ajoy Basin.

\begin{tabular}{|c|c|c|c|c|c|}
\multicolumn{9}{|c}{ Table 01: Spatio-Temporal Pattern of Flood in Lower Ajoy Basin } \\
\hline \multirow{2}{*}{ Year } & \multicolumn{2}{|c|}{ Flood Affected Mouzas } & \multicolumn{2}{c|}{$\begin{array}{c}\text { Affected Areas } \\
\text { (sq.km) }\end{array}$} & $\begin{array}{c}\text { Percent to the } \\
\text { total basin }\end{array}$ \\
\cline { 2 - 4 } & Entirely & Partially & Total & 680.0 & 24.14 \\
\hline 1956 & 153 & 32 & 185 & 584.38 & 20.74 \\
\hline 1959 & 120 & 27 & 147 & 812.24 & 28.83 \\
\hline 1970 & 186 & 36 & 222 & 624.71 & 22.81 \\
\hline 1971 & 130 & 31 & 161 & 639.02 & 22.68 \\
\hline 1973 & 124 & 36 & 160 & 1680.0 & 59.64 \\
\hline 1978 & 307 & 67 & 374 & 305.72 & 10.85 \\
\hline 1984 & 78 & 20 & 98 & 1380.82 & 48.99 \\
\hline 1995 & 227 & 49 & 276 & 1408.0 & 49.98 \\
\hline 1999 & 237 & 60 & 297 & 1488.0 & 52.82 \\
\hline 2000 & 263 & 106 & 369 & 706.54 & 25.08 \\
\hline 2008 & 136 & 39 & 175 & 764.23 & 27.12 \\
\hline 2015 & 152 & 46 & 198 & \\
\hline
\end{tabular}

Source: Irrigation and Waterways Department, Government of West Bengal, 2017

In the Lower Ajoy river basin ten major floods have been recorded since 1956 ,which occurred in $1956,1959,1970,1971,1973,1978,1995,1999,2000,2008$ and 2015 . The individual maps for the major floods have been prepared. All the maps have been superimposed over each other in two sets (five year each) to identify the area under maximum, moderate and minimum number of occurrences (Figure 04). By this way four zones (Table 03) have been demarcated on the basis of frequency of flood occurrences.

- $\quad$ High / severe flood prone zone (F1).

- Medium / moderate flood prone zone (F2).

- Low flood prone zone (F3).

- Flood free zone (F0).+ 
Figure 02: Inundation of Lower Ajoy Basin (IRS P6 LISS-III 2008)
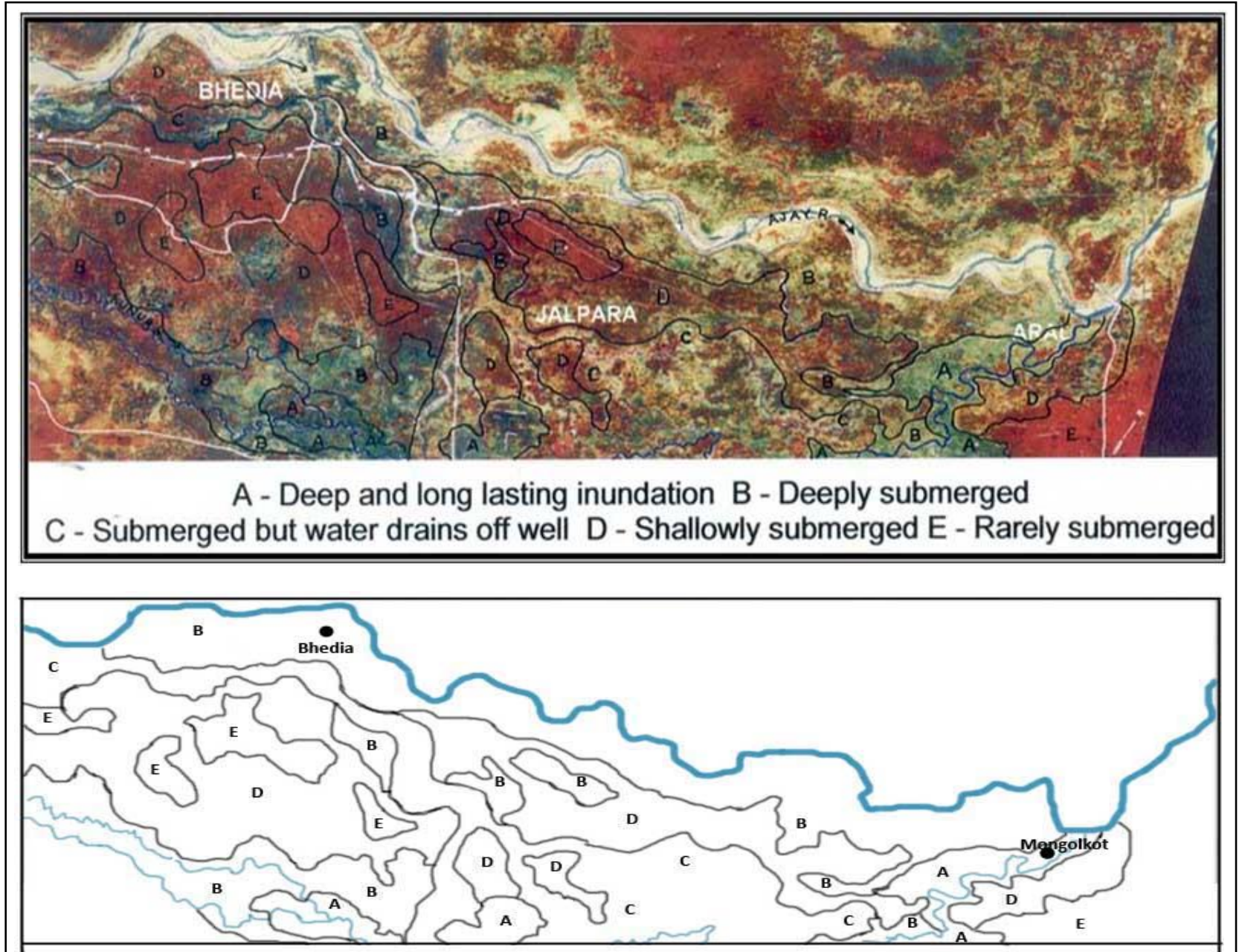

A - Deep and long lasting inundation B - Deeply submerged

C - Submerged but water drains off well D - Shallowly submerged E - Rarely submerged

Figure 03: Relationship between Flood Affected rea

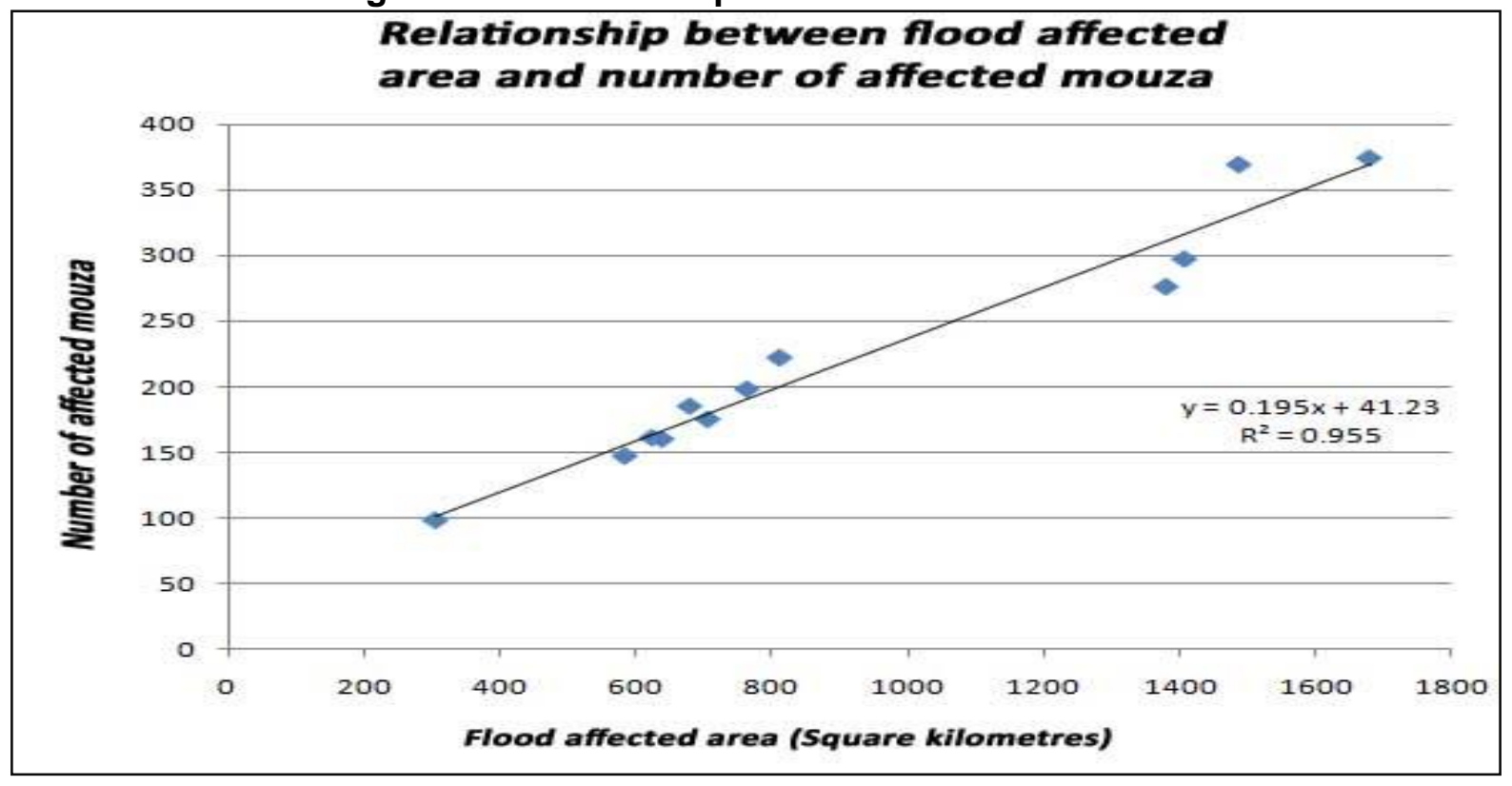


Table 02: Highest Flood Level in Different Gauge Station (1956- 2015)

\begin{tabular}{|l|l|l|l|l|l|l|l|l|l|l|l|l|}
\hline Gauge & Danger \\
station & $\begin{array}{l}\text { Level } \\
\text { (metres) }\end{array}$ & 1956 & 1959 & 1970 & 1971 & 1973 & 1978 & 1995 & 1999 & 2000 & 2008 & 2015 \\
\hline Beta & 57.90 & 61.05 & $\begin{array}{l}\text { No } \\
\text { spilling }\end{array}$ & $\begin{array}{l}\text { No } \\
\text { spilling }\end{array}$ & 59.60 & $\begin{array}{l}\text { No } \\
\text { spilling }\end{array}$ & 61.14 & 59.75 & 60.70 & 61.50 & 61.19 & $\begin{array}{l}\text { No } \\
\text { spilling }\end{array}$ \\
\hline Satkahonia & 51.75 & 54.41 & $\begin{array}{l}\text { No } \\
\text { spilling }\end{array}$ & 53.50 & 53.10 & 53.48 & 55.44 & 54.42 & 54.68 & 54.90 & $\begin{array}{l}\text { No } \\
\text { spilling }\end{array}$ & $\begin{array}{l}\text { No } \\
\text { spilling }\end{array}$ \\
\hline Maliara & 41.70 & 45.37 & 45.58 & 44.17 & 44.47 & 43.16 & 45.71 & 45.72 & 44.46 & 45.86 & 44.76 & 43.10 \\
\hline Gheropara & 39.14 & 40.89 & 41.31 & 40.51 & 40.29 & 40.63 & 42.82 & 42.50 & 43.22 & 42.79 & 41.10 & $\begin{array}{l}\text { No } \\
\text { spilling }\end{array}$ \\
\hline Nutanhat & 19.19 & 21.02 & 21.84 & 20.40 & 20.62 & 20.00 & 22.42 & 22.30 & 22.89 & 23.21 & 21.34 & 20.21 \\
\hline
\end{tabular}

Source: Irrigation and Waterways Directorate, Govt. of West Bengal-2017

\section{Severe Flood Prone Zone}

It covers an area of about 624.46 square $\mathrm{km}$, which accounts 22.17 per cent out of the total Lower Ajoy Basin. This is highly flood affected zone and runs almost parallel to the river basin. But in the right bank it extends up to $8 \mathrm{~km}$ (in Ausgram block). In Ketugram block this zone is broadened towards the east and extends 3 to $4 \mathrm{~km}$ from the river bank. It is estimated that out of the total 619 moujas 144 moujas are highly flood prone, which faced flood almost in every flood occurrences. The frequency of occurrences of flood in this zone is more than 60 percentages. Sandsplays, Ox-bow lakes, Meander scrolls, etc. are the major geomorphic features in this zone. The river in this zone is predominantly characterized by elevated river banks (levee). This is a result of either man made intervention in the form of embankment or built up natural levees by sediment laden water. Multiplicity of abandoned channels, decadent rivers and depressions due to fluvial erosion are the natural consequences. In this zone the danger level of flood height at some gauge stations like Beta, Satkahonia, Maliara, Gheropara and Nutanhat are 57.90, 51.75, 41.70, 39.41, and 19.19 metres respectively but the actual flood height in 2000's flood were 61.50, 54.90, 45.86, 42.79, and 23.21 metres respectively (Table:2). The loss of agricultural land and crops due to sands play caused by breaching of embankment becomes a great threat to the dwellers living in highly flood prone zone. This zone is characterized by deep and long lasting inundation (Figure: 2)

\section{Moderate Flood Prone Zone}

This zone occupies 528.00 square $\mathrm{km}$ and covers 18.75 per cent out of the total Lower Ajoy river basin area. Out of total 619 moujas 130 falls under this zone. In this zone the frequency of occurrences of flood is $40-60$ percentages. The predominant geomorphic features of this zone are abandoned channels, cut-off channels, back swamps, etc. Gradual depositions of silt on the back swamps have turned them into shallow swampy and 'beel' areas. During the rainy season over-flooding of areas adjoining the 'beels' become a common feature. The coverage of medium flood prone zone is more on the right bank of the river than the left bank. In this zone the houses, livestock and other assets have been lost more than agricultural crops.

\section{Low Flood Prone Zone}

This zone extends between the medium flood prone zone and the flood free zone. It occupies 576.30 square $\mathrm{km}$, which accounts 20.46 per cent out of the total Lower Ajoy river basin. It is estimated that about 219 moujas are located in this zone. It is characterized by less than 40 percentages of frequency of flood occurrences. The geomorphic features are slightly varies from western part to the eastern part of the basin particularly on the left bank side of the river. In this zone particularly in the western portion, there are appearances of isolated terraces and highland flood plain. Some old channels courses are found in the form of abandoned and morbid channels which are now filled with water, forming swamps and 'beels'. In this zone the flood induced devastation is quite little.

\section{Flood Free Zone}

Next to low flood prone area, there is another zone which is still totally free from flood. This zone covers 1087.89 square km which accounts 38.62 per cent out of the total Lower Ajoy river basin. About 126 moujas are located in this zone. Beyond this zone in the north, there is Mayurakshi river basin and in south, there is Damodar river basin. The flood free zone consists of micro-geographic features like terraces, slight dissected land, highland features. This zone is having marked characteristics of high relief, undulations, rolling and gently level topography with the preponderance of rills, sheet wash, and gullies which are typical in its landform pattern. 
Table 03: Status of flood affected zones in Lower Ajoy Basin

\begin{tabular}{|c|l|c|c|c|c|}
\hline$\#$ & \multicolumn{1}{|c|}{ Zone } & $\begin{array}{c}\text { Area } \\
\mathbf{k m}^{2} \mathbf{)}\end{array}$ & $\begin{array}{c}\text { No. of affected } \\
\text { Mouja }\end{array}$ & $\begin{array}{c}\text { \% of the } \\
\text { basin area }\end{array}$ & $\begin{array}{c}\text { Frequency of } \\
\text { occurrences (\%) }\end{array}$ \\
\hline 1 & High/severe flood prone & 624.46 & 144 & 22.17 & $>60$ \\
\hline 2 & $\begin{array}{l}\text { Medium/moderate flood } \\
\text { prone }\end{array}$ & 528.00 & 130 & 18.75 & $40-60$ \\
\hline 3 & Low flood prone & 576.30 & 219 & 20.46 & $<40$ \\
\hline 4 & Flood free & 1087.89 & 126 & 38.62 & -- \\
\hline
\end{tabular}

Source: Block Development Offices of Burdwan and Birbhum districts-2017

Figure 04: Flood Intensity Map

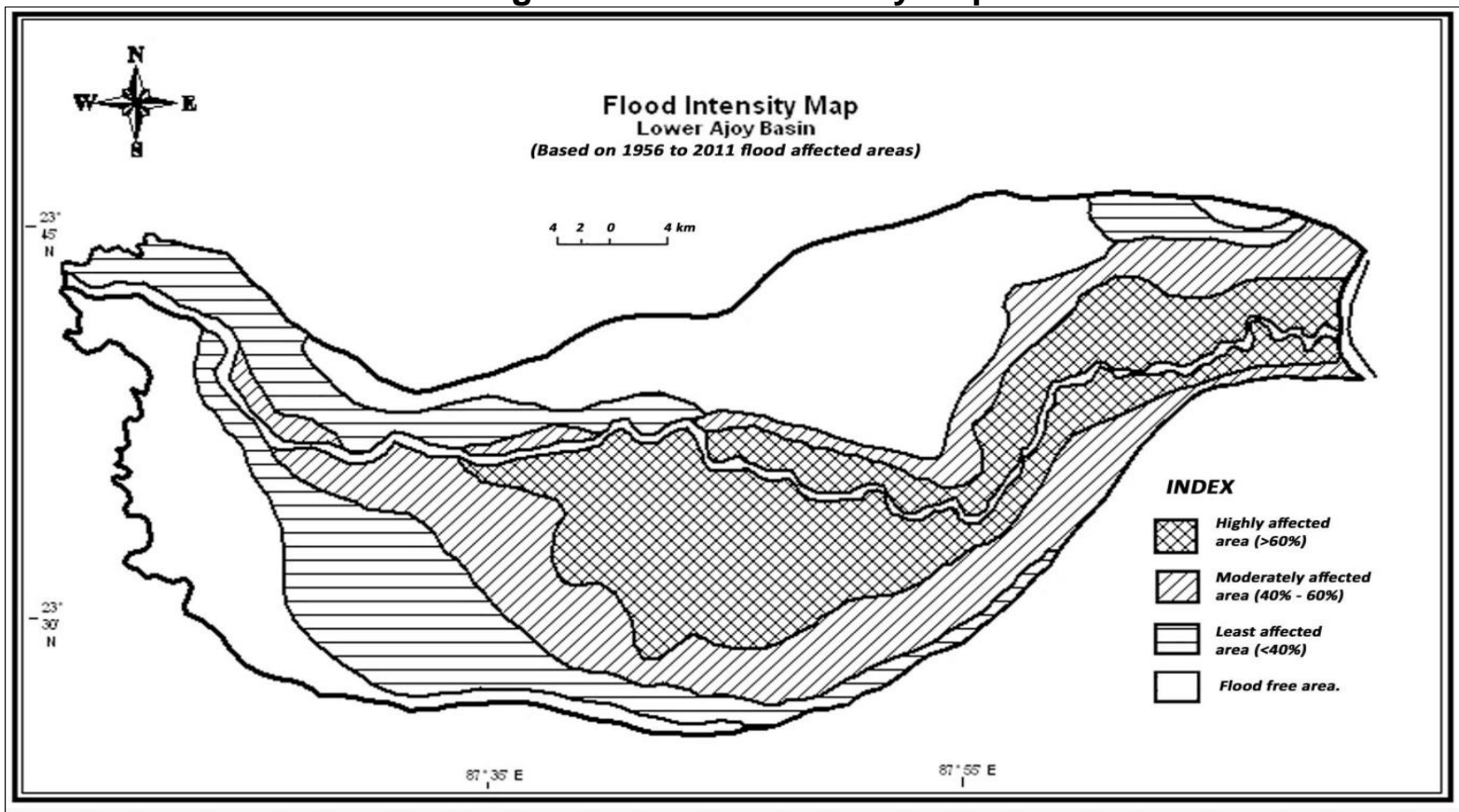

\section{Proposed Remedial Measures}

The traditional management response to a severe flood was typically an ad hoc reaction to the natural process. The quick implementation of a project that considered both the problem and its solution to be self-evident, and that gave no thought to the consequences for upstream and downstream flood risks. Thus, flood management practices have largely focused on reducing flooding and reducing the susceptibility to flood damage. Traditional flood management has employed structural and non-structural interventions, as well as physical and institutional interventions (Let, 2012). These interventions have occurred before, during and after flooding, and have often overlapped.

\section{Conclusion}

It is quite natural that every river has of its own 'river arena' in which the river performs its various natural processes, like bank erosion, meandering, shifting of river channel etc. But in the name of 'flood control' we are consciously or unconsciously destroying the 'river arena'. This is the only reason of flood fury in most of the river basins. The Lower Ajoy river basin is characterized by very gently sloping floodplain. Most of the time the river flows within its normal course but during monsoon period because of the hydrological factors like heavy runoff and geomorphic factors like plain and low lying area, it overflows beyond the normal channel and thus causing great harm to human activities and properties. It can be mentioned that extent of flood prone area is more on the right bank of the river than the left bank. However it can be concluded that the flood damage is a function of the extent of flood affected area, depth of inundation, duration of submergence, frequency of flooding, standing crop area affected and its value, value of public and private properties and utilities affected and nonphysical damages. In the study area flood control is being practiced since centuries. As flood cannot be totally controlled and it is not possible to provide protection against all magnitude of flood, we have to adjust with the flood and implementation of proper flood management programmes become very much necessary. Along with the structural measures like construction of reservoirs, embankments, detention basins, river channel and drainage 
improvement diversions of flood water etc., proper weightage must be given to the nonstructural measures like flood forecasting and warning system, flood plain zoning, disaster preparedness, relief and rehabilitation, etc. Thus the traditional sectoral planning approach for complete flood control should be changed to sustainable flood plain development policy (Haque et. al. 1993). Preparation of floodplain zoning map (Figure: 4) is an important non-structural measure to mitigate flood hazard. Degree of vulnerability of flood can be identified by demarcating the high, medium, and low flood prone zone and proper planning of land-use of the individual zone can be made accordingly. Government may launch different insurance packages for the people living in different flood prone zone. Instead of making trifle attempts to protect floods, we should try to adjust with floods keeping the view that flood is a natural phenomenon and our relationship with rivers should be reciprocal in nature.

\begin{tabular}{|l|l|}
\hline \multicolumn{1}{|c|}{ Strategy } & \multicolumn{1}{c|}{ Options } \\
\hline \multirow{4}{*}{ Reducing Inundation } & Dams and reservoirs \\
\cline { 2 - 2 } & Dikes, levees and flood embankments \\
\cline { 2 - 2 } & High flow diversions \\
\cline { 2 - 2 } & Catchment management \\
\cline { 2 - 2 } & Channel improvements \\
\hline \multirow{4}{*}{ Reducing Susceptibility to Damage } & Floodplain regulation \\
\cline { 2 - 2 } & Development and redevelopment policies \\
\cline { 2 - 2 } & Design and location of facilities \\
\cline { 2 - 2 } & Housing and building codes \\
\cline { 2 - 2 } & Flood proofing \\
\cline { 2 - 2 } & Flood forecasting and warning \\
\hline \multirow{4}{*}{ Mitigating the Impacts of Flooding } & Information and education \\
\cline { 2 - 2 } & Disaster preparedness \\
\cline { 2 - 2 } & Post-flood recovery \\
\cline { 2 - 2 } & Flood Insurance \\
\hline Preserving the Natural Resources of Flood Plains & Floodplain zoning and regulation \\
\hline
\end{tabular}

\section{References}

1. Bhattacharjee, N.G. (1995) Mitigation of Flood Problem in West Bengal, Directive Initiative, Calcutta.

2. Haque, C. Emdad and Zaman, M.Q. (1993) Human Response to Riverine Hazard in Bangladesh A Proposal for Sustainable Flood Plain Development, World Development, vol-21,

3. Hewitt, K. and Burton, I. (1971) The Hazardness of place: A Regional Ecology of Damaging Events, University of Jorants, Dept. of Geography, Research publication.

4. Kar, S. (1999) The Flood Situation in West Bengal, Agenda for Action, Directive Initiative, Calcutta.

5. Kazi, Md. F. Haq and Bhuiyan R.H. (2004) Delineation and Zonation of Flood Prone Area: A Case Study of Tangail District, Bangladesh, Indian Journal of Regional Science, vol. XXXVI.

6. Let, S. (2012) Spatio-temporal changes of flood characteristics in the Dwarka River Basin, Visva-Bharati University.

7. Magura, L.M. and Wood D.E. (1980) Flood Hazard Identification and Flood Plain Management on Alluvial Fan, Water Resources Bulletin.

8. Niyogi, M. (1987) Flood Frequency and Management Analysis of Lower Ajoy Basin, Indian Journal of Landscape system and Ecological Studies, vol. 10 Calcutta.

9. Smith, K. and Tobin, G.A. (1979). Human Adjustment to the Flood Hazard, Longman, London.

10. Ward, R. (1978) Floods, A Geographical Perspective, Macmillan Press Ltd. London. 